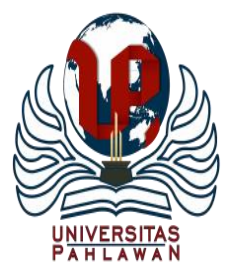

Edukatif : Jurnal Ilmu Pendidikan Volume 3 Nomor 4 Tahun 2021 Halm 1765 - 1774

EDUKATIF: JURNAL ILMU PENDIDIKAN

Research \& Learning in Education

https://edukatif.org/index.php/edukatif/index

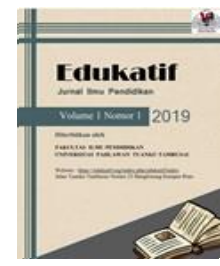

\title{
Efektivitas Model Pembelajaran Blended Learning Untuk Meningkatkan Keterampilan Berpikir Kritis Peserta Didik Pada Pelajaran Ekonomi
}

\author{
Husaeri Ardika Dwi Putra ${ }^{1 凶}$, Dhiah Fitrayati ${ }^{2}$ \\ Universitas Negeri Surabaya, Indonesia ${ }^{1,2}$ \\ E-mail : husaeri.17080554073@ mhs.unesa.ac.id ${ }^{1}, \underline{\text { dhiahfitrayati@unesa.ac.id }}^{2}$
}

\begin{abstract}
Abstrak
Peran guru dalam memilih model pembelajaran daring sangat penting pada tercapainya tujuan pembelajaran. Tujuan dari penelitian ini yaitu melihat efektivitas model pembelajaran blended learning dalam peningkatan keterampilan berpikir kritis siswa dilihat berdasarkan jawaban kritis siswa pada saat mengerjakan soal sesuai indikator yang ada pada keterampilan berpikir kritis. Metode yang digunakan pada penelitian ini adalah penelitian eksperimen percobaan dengan desain Quasi experimental Design (experiment semu). Menurut Dicky, quasi experimental design merupakan sebuah penelitian yang penempatan subjeknya tidak dipilih secara acak, baik didalam kelompok eksperimen maupun kelompok kontrol. Hasil analisis uji validitas, soal untuk pretest dan posttest dinyatakan valid. Selanjutnya dilakukan uji reliabilitas dan hasilnya dinyatakan reliabel. Butir soal yang sudah valid dan reliabel tersebut dapat digunakan dalam kegiatan pretest dan posttest. Setelah diberikan perlakuan, nilaipeserta didik mengalami kenaikan. Distribusi subjek penelitian adalah tidak normal. Pada uji wilcoxon dieproleh hasil yang menyatakan peningkatan nilai pada peserta didik, dengan demikian bisa dikatakan bahwa blended learning efektif dalam meningkatkan keterampilan berpikir kritis peserta didik.
\end{abstract}

Kata Kunci: Model Pembelajaran Blended Learning, Keterampilan Berpikir Kritis, Online

\begin{abstract}
The teacher's role in choosing an online learning model is very important in achieving learning objectives. The purpose of this study is to see the effectiveness of the blended learning model in improving students critical thinking skills based on students' critical answers when working on questions according to the indicators on critical thinking skills. The method used in this research is experimental research with a Quasiexperimental design. According to Dicky, a quasi-experimental design is a study in which the placement of the subjects is not chosen at random, either in the experimental group or the control group. The results of the analysis of the validity test, the questions for the pretest and posttest were declared valid. Furthermore, the reliability test was carried out and the results were declared reliable. The items that are already valid and reliable can be used in pretest and posttest activities. After being given treatment, the value of students has increased. The distribution of research subjects was not normal. In the Wilcoxon test, the results showed an increase in the value of students, thus it can be said that blended learning is effective in improving students' critical thinking skills.
\end{abstract}

Keywords: Blended Learning Model, Critical Thinking Skills, Online

Copyright (c) 2021 Husaeri Ardika Dwi Putra, Dhiah Fitrayati

$\triangle$ Corresponding author:

Email : husaeri.17080554073@mhs.unesa.ac.id

DOI : https://doi.org/10.31004/edukatif.v3i4.676

ISSN 2656-8063 (Media Cetak)

ISSN 2656-8071 (Media Online)

Edukatif : Jurnal Ilmu Pendidikan Vol 3 No 4 Tahun 2021 p-ISSN 2656-8063 e-ISSN 2656-8071 
1766 Efektivitas Model Pembelajaran Blended Learning Untuk Meningkatkan Keterampilan Berpikir Kritis Peserta Didik Pada Pelajaran Ekonomi - Husaeri Ardika Dwi Putra, Dhiah Fitrayati

DOI: https://doi.org/10.31004/edukatif.v3i4.676

\section{PENDAHULUAN}

Banyak negara yang mengalami dampak pandemi covid-19, tak terkecuali negara Indonesia. Virus ini menular dengan sangat cepat. Word Health Organization (WHO) menghimbau agar kegiatan yang berpotensi menimbulkan keramaian untuk sementara dihentikan agar penyebaran covid-19 dapat dicegah (Handarini \& Wulandari, 2020). Hal tersebut membuat berbagai negara harus menerapkan sistem lockdown untuk menekan persebaran dari virus corona lebih luas lagi. Namun Pemerintah Indonesia menerapkan sistem Pembatasan Sosial Berskala Besar (PSBB) sebagai antisipasi serta menekan persebaran Virus tersebut. Sejak penerapan PSBB, sistem pendidikan yang awalnya diterapkan secara tatap muka di sekolah bergeser ke sistem pembelajaran jarak jauh (daring), dimana siswa belajar dan melakukan aktivitas di rumah (Yoga Purandina \& Astra Winaya, 2020).

Para pendidik memanfaatkan pembelajaran daring untuk mempermudah proses belajar mengajar selama pandemi (Hidayah et al., 2020). Fleksibilitas merupakan salah satu sifat dari pembelajaran jarak jauh yang memungkinkan pelaksanaan pembelajaran dalam kondisi apapun dan dimanapun (Ratu et al., 2020). Aplikasi seperti whatsapp, google meeting, google classroom dan aplikasi belajar lainnya yang dapat dimanfaatkan oleh pendidik dalam pembelajaran daring pada masa pandemi seperti saat ini (Sukirwan, 2020). Keterampilan berpikir kritis peserta didik menjadi tidak maksimal merupakan dampak dari pembelajaran daring, sebab selama pembelajaran daring peserta didik kurang mampu menganalisis sebuah kasus yang diberikan oleh guru (Cahyadi et al., 2012). Pembelajaran secara daring masih bisa dikatakan belum efektif, pada setiap indikator diperoleh nilai rata-rata yakni $<60 \%$ yang didapatkan peserta didik (Safriandi et al., 2021).

Peran guru dalam memilih model pembelajaran daring sangat penting pada tercapainya tujuan pembelajaran. Model pembelajaran blended learning dianggap cocok untuk diterapkan dalam pembelajaran daring pada kondisi seperti ini. Karena dalam model pembelajaran blended learning mampu memadukan proses sinkron dan asinkron sehingga lebih memudahkan tercapainya tujuan pembelajaran. Menurut (Cronje, 2020) untuk memaksimalkan proses pembelajaran dalam sebuah konteks tertentu, model pembelajaran blended learning mencampurkan teori, metode dan teknologi. Menurut (Idris, 2018) melalui metode penggabungan pembelajaran secara tatap muka, dukungan teknologi berupa bahan cetak, dukungan teknologi audio, audio visual, komputer, dan adanya teknologi m-learning (mobile learning) merupakan ciri-ciri dari pembelajaran berbasis blended learning. Sedangkan menurut Whittaker (dalam Sharma, 2010) penggabungan antara pembelajaran luring dengan online merupakan model pembelajaran blended learning. Oleh karenanya, terdapat unsur-unsur dalam blended learning yang akan membantu mempermudah dalam mencapai tujuan pembelajaran. Unsur tersebut antara lain konvensional (secara langsung), belajar sendiri, penerapan, tata cara, kerjasama dan penilaian (evaluasi) (Idris, 2018).

Pada implementasi proses pembelajaran dengan blended learning perlu rancangan yang matang untuk menciptakan proses pembelajaran yang bermakna dan keterampilan pada peserta didik (Zurita et al., 2015). Menurut Ananda dkk (dalam Ramadani et al., 2019) Terdapat beberapa faktor yang mempengaruhi keberhasilan penerapan pembelajaran blended learning, diantaranya sumber daya manusia, lingkungan belajar, serta sarana dan prasarana. Sumber daya manusia disini mencakup pengajar sebagai tenaga ahli untuk menuntun dan membimbing peserta didik mampu menjalankan proses pembelajaran dengan efektif, selain itu peserta didik juga memiliki peran pada pelaksanaan proses pembelajaran, karena mereka dituntut agar mampu belajar mandiri dengan bimbingan pengajar secara daring. Lingkungan belajar merupakan faktor penunjang proses pembelajaran dengan model blended learning, dengan lingkungan belajar yang nyaman membuat peserta didik dapat menerima materi pembelajaran dengan maksimal dan dapat menuangkan kreatifitasnya. Sarana dan prasarana dalam model pembelajaran blended learning ini mencakup smartphone/laptop/computer dan jaringan internet untuk memudahkan dalam melakukan proses pembelajaran jarak jauh. 
1767 Efektivitas Model Pembelajaran Blended Learning Untuk Meningkatkan Keterampilan Berpikir Kritis Peserta Didik Pada Pelajaran Ekonomi - Husaeri Ardika Dwi Putra, Dhiah Fitrayati

DOI: https://doi.org/10.31004/edukatif.v3i4.676

Menurut Charles R. Graham (dalam Yu, 2015) pembelajaran berbasis blended learning digunakan pada proses pembelajaran karena mampu meningkatkan pedagogik pendidik, meningkatkan fleksibilitas dan akses, serta meningkatkan efektifitas biaya. Penerapan model pembelajaran blended learning memiliki tingkat fleksibilitas yang tinggi, seperti dapat dengan mudah menyesuaikan waktu yang dimiliki pendidik dan peserta didik dan proses pembelajaran akan tetap efektif meskipun peserta didik dalam jumlah banyak (López-Pérez et al., 2011). Menurut Kusairi (dalam Wardani et al., 2018) mengatakan bahwa kelebihan model blended learning dari model yang lain yaitu: a. Materi yang sudah tersedia secara online dapat memudahkan siswa untuk mempelajarinya secara mandiri. b. Kemudahan dalam berdiskusi dengan pendidik atau siswa lainnya karena tidak terbatas ruang dan waktu. c. Pendidik lebih mudah mengatur dan mengelola kelas di luar jam tatap muka. d. Pendidik lebih mudah dalam menambah maupun merevisi materi secara online. e. Proses pembelajaran dapat dilakukan dengan lebih efektif. f. Peserta didik akan lebih mudah dalam berbagi file dengan pendidik maupun peserta didik lainnya. Selain itu terdapat langka-langkah atau sintak pembelajaran dalam blended learning sebagai acuan pendidik dalam melaksanakan kegiatan pembelajaran menerapkan model belajar blended learning. Model pembelajaran seperti ini juga berpengaruh secara signifikan pada keterampilan berpikir kritis peserta didik (Ningsih et al., 2018).

SMA Negeri 1 Rengel yang terletak pada Desa Banjaragung Kecamatan Rengel Kabupaten Tuban yang jauh dari pusat kota Tuban. Hasil pengamatan menunjukkan bahwa kegiatan belajar mengajar yang dialami peserta didik memiliki kendala antara lain jaringan internet yang kurang mendukung. Permasalahan yang timbul dari kendala tersebut yaitu kurang aktifnya peserta didik terjadinya proses belajar dan dapat dilihat dengan kondisi peserta didik yang kurang mampu menjabarkan dari sebuah kasus dari guru, sehingga jawaban yang diberikan peserta didik tidak tepat dengan point jawaban yang seharusnya ada dalam soal studi kasus tersebut. Sehingga kemampuan peserta didik dalam berpikir kritis termasuk dalam kategori yang kurang maksimal.

Bekal yang seharusnya dimiliki oleh peserta didik dalam memahami dan menghadapi adanya perkembangan lebih pesat pada ilmu pengetahuan dan teknologi saat ini adalah kemampuan berpikir secara lebih maju dan memiliki pola pikir perspektif jauh kedepan. Kemampuan berpikir yang dimiliki peserta didik dapat memenuhi kebutuhan intelektual dan membantu peserta didik untuk mengembangkan potensi yang dimilikinya. Dalam beberapa tahun terakhir berpikir kritis telah dikenal dan tidak lagi asing dalam dunia pendidikan. Kemampuan berpikir kritis yang dimiliki individu dapat membantunya dalam menyelesaikan masalah secara terstruktur dan logis berdasarkan fakta yang ada (Rachmantika \& Wardono, 2019). Berpikir kritis mulai dibiasakan dan diterapkan oleh guru, khususnya pada saat proses pembelajaran. Menurut Richard Paul (dalam Prastowo et al., 2019) Berpikir kritis merupakan salah satu cara berpikir yang disertai dengan adanya peningkatan pemikiran dengan terampil pada struktur dan standar intelektualnya. Penerapan model belajar yang tepat bisa menaikkan keterampilan berpikir secara kritis peserta didik.

Penelitian terdahulu yang relevan dengan penelitian ini sehingga dapat memperkuat dilakukan oleh (Lestari et al., 2016). Hasil dari penelitian terdahulu terdapat pengaruh berupa peningkatan keterampilan berpikir kritis setelah diterapkannya model pembelajaran blended learning. Pada kedua penelitian ini memiliki persamaan yaitu pada tujuan penelitian untuk menganalisis efektivitas model pembelajaran blended learning untuk meningkatkan kemampuan berpikir kritis peserta didik. Terdapat perbedaan pada metode penelitian. Penelitian sebelumnya menggunakan metode pengembangan (research and development) dengan mengadaptasi model 4D (four D model). Sedangkan penelitian ini menggunakan metode eksperimen percobaan dengan desain Quasi experimental Design (experiment semu).

Penelitian selanjutnya yang relevan dengan penelitian ini dilakukan oleh (Fariska \& Erman, 2017). Hasil dari penelitian yaitu model pembelajaran blended learning dapat meningkatkan keterampilan nerfikir kritis peserta didik.pada kedua penelitian ini memiliki persamaan pada tujuan penelitian untuk menganalisi efektivitas model pembelajaran blended learning untuk meningkatkan keterampilan berpikir kritis peserta 
1768 Efektivitas Model Pembelajaran Blended Learning Untuk Meningkatkan Keterampilan Berpikir Kritis Peserta Didik Pada Pelajaran Ekonomi - Husaeri Ardika Dwi Putra, Dhiah Fitrayati

DOI: https://doi.org/10.31004/edukatif.v3i4.676

didik. Persamaan lainnya yaitu kedua penelitian sama menggunakan metode penelitian eksperimen. Terdapat perbedaan pada pengambilan data, penelitian terdahulu mengambil data lengkap beserta respon peserta didik melalu angket. Sedangkan penelitian ini hanya tidak dengan respon peserta didik.

Tujuan dari penelitian ini yaitu melihat efektivitas model pembelajaran blended learning dalam peningkatan keterampilan berpikir kritis siswa dilihat berdasarkan jawaban kritis siswa pada saat mengerjakan soal sesuai indikator yang ada pada keterampilan berpikir kritis. Penelitian ini diharapkan mampu mendorong siswa mengikuti pembelajaran dengan model pembelajaran blended learning agar terjadi peningkatan pada keterampilan berpikir kritis. Selain itu, penelitian ini bisa menjadi acuan bagi pendidik dan berbagai pihak dalam menambah kualitas pengajaran dengan menerapkan model blended learning.

\section{METODE PENELITIAN}

Metode yang digunakan pada penelitian ini adalah penelitian eksperimen percobaan dengan desain Quasi experimental Design (experiment semu). Menurut Dicky, quasi experimental design merupakan sebuah penelitian yang penempatan subjeknya tidak dipilih secara acak, baik didalam kelompok eksperimen maupun kelompok kontrol (Hastjarjo, 2019). SMA Negeri 1 Rengel, Tuban merupakan sekolah yang dijadikan tempat pelaksaan peneliti. Sekolah yang berlokasi di JL. Raya Banjaragung, Rengel, Dusun Gumeng, Banjaragung, Kabupaten Tuban. Poulasi dalam penelitian ini adalah seluruh peserta didik kelas XI IPS 2 SMA Negeri 1 Rengel sebanyak 30 anak. Sedangkan sampel dalam penelitian ini adalah seluruh populasi. Populasi penelitian kurang dari 100, menurut Arikunto (Yulfianti \& Dewi, 2021) sampel dengan menggunakan seluruh populasi yang kurang dari 100 merupakan sampel jenuh.

Blended Learning yang digunakan pada penelitian ini yaitu jenis blended learning rotation. Dalam bentuk blended learning ini, peserta didik mengikuti jadwal untuk berotasi antara mengikuti pelajaran daring atau tatap muka secara langsung dengan guru. Pembelajaran dilakukan sebanyak 2 kali tatap pertemuan, dimana 1 kali pertemuan dilakukan secara online dan 1 kali pertemuan lagi dilakukan secara tatap muka. Dalam pembelajaran online, peserta didik diberikan kesiapan materi dan dibentuk kelompok untuk dilakukan pada pertemuan tatap muka. Pada saat tatap muka peserta didik diminta bergabung dengan kelompok yang telah dibentuk pada saat pembelajaran online untuk menganalisis studi kasus yang diberikan oleh guru

Menggunakan desain penelitian Quasi experimental Design (experiment semu) dengan rancangan onegroup pretest-posttest design. Sebelum diberikan perlakuan, peserta didik diberikan soal pretest untuk mengetahui tingkat kemampuan awal berpikir kritis. Selanjutnya diberikan tindakan yaitu model pembelajaran berbasis blended learning. Setelah mendapatkan perlakuan, siswa diberikan soal posttest untuk mengukur tingkat kemampuan berpikir kritis setelah memperoleh perlakuan. Berikut merupakan desain penelitian one group pretest posttest design.

Tabel 1

\begin{tabular}{ccc}
\multicolumn{3}{c}{ Desain penelitian one group pretest posttest design } \\
\hline Pretest & Treatment & Posttest \\
\hline $\mathrm{O}_{1}$ & $\mathrm{X}$ & $\mathrm{O}_{2}$ \\
\hline
\end{tabular}

Instrumen yang dipergunakan pada penelitian yaitu wawancara, rpp, pretest serta posttest. Wawancara dilakukan dengan guru ekonomi SMA Negeri 1 Rengel guna mendapatkan informasi yang bersangkutan dengan permasalahan yang dialami peserta didik selama pembelajaran jarak jauh. Instrumen rpp dengan model pembelajaran blended learning digunakan sebagai pedoman untuk proses pembelajaran secara sinkron maupun asinkron. Instrumen tes terdiri dari pretest dan posttest digunakan sebagai pengukur keterampilan berpikir kritis siswa. Instrumen dari tes berikut adalah soal berbasis kemampuan berpikir tingkat tinggi dengan level kompetensi minimal adalah $\mathrm{C} 4$. Sebelum tes diujikan pada peserta didik dilakukan pengujian validitas dan reliabilitas tes terlebih dahulu. 
1769 Efektivitas Model Pembelajaran Blended Learning Untuk Meningkatkan Keterampilan Berpikir Kritis Peserta Didik Pada Pelajaran Ekonomi - Husaeri Ardika Dwi Putra, Dhiah Fitrayati

DOI: https://doi.org/10.31004/edukatif.v3i4.676

Ada tidaknya peningkatan kemampuan berpikir kritis peserta didik melalui perbedaan nilai pretest dan posttest akan dibuktikan menggunakan uji t. Namun sebelum melakukan uji t maka dilakukan pengujian prasyarat terlebih dulu yaitu uji normalitas. Pengujian tersebut bertujuan agar data yang didapatkan terdistribusi normal atau tidak. Uji normalitas tersebut merupakan syarat mutlak yang harus dipenuhi sebelum melakukan uji-t. Efektivitas atau pengaruh pasca dilakukannya pembelajaran menggunakan model pembelajaran berbasis blended learning dipantau pada perbedaan skor pretest $(\mathrm{O} 1)$ dan posttest $(\mathrm{O} 2)$ jika terdapat perbedaan nilai dari kedua test, dimana nilai yang diperoleh ketika mengerjakan pretest $(\mathrm{O} 1)$ lebih rendah daripada skor posttest (O2), jadi dapat disimpulkan bahwa pada masa pandemi seperti sekarang, model pembelajaran blended learning efektif diterapkan pada siswa.

\section{HASIL DAN PEMBAHASAN PENELITIAN}

Model pembelajaran blended learning ini diharapkan dapat mendorong terjadinya peningkatan pada keterampilan berpikir kritis peserta didik. Soal pretest dan posttest digunakan untuk mengukur keterampilan berpikir kriti. Sebelum diujikan pada peserta didik, soal pretest dan posttest diukur dahulu dengan menggunakan uji validitas dan reliabilitas.

Uji validitas digunakan sebagai pengukur soal bisa dikatakan valid atau tidak. Soal dinyatakan valid apabila nilai korelasi product moment pearson minimal 0,66 dengan tingkat signifikansi $\leq$ 0,05 oleh Sugiyono (dalam Indrawan \& Kaniawati Dewi, 2020). Hasil analisis menunjukkan bahwa nilai korelasi product moment person dari 6 butir soal memiliki nilai korelasi product moment pearson minimal 0,66 dengan tingkat signifikansi $\leq 0,05$ dan dinyatakan valid. Artinya butir soal memiliki tingkat validitas yang kuat. Selanjutnya pada butir soal yang dinyatakan valid tersebut dilakukan uji reliabilitas.

Uji reliabilitas butir soal diterapkan sebagai pengukur tingkat reliabel butir soal. Reliabilitas butir soal dapat dilihat dari nilai Guttman Spaerman-Brown Coefficien. Berdasarkan hasil analisis data diperoleh nilai Guttman Spaerman-Brown Coefficien adalah sebesar 0,866 yang artinya butir soal memiliki tingkat reliabilitas sangat kuat. Butir soal yang sudah valid dan reliabel tersebut dapat digunakan dalam kegiatan pretest dan posttest. Interpretasi koefisien korelasi untuk menentukan validitas dan reliabilitas termasuk dalam tingkatan sangat rendah, rendah, sedang, kuat, dan sangat kuat dinyatakan oleh Sugiyono (dalam Indrawan \& Kaniawati Dewi, 2020).

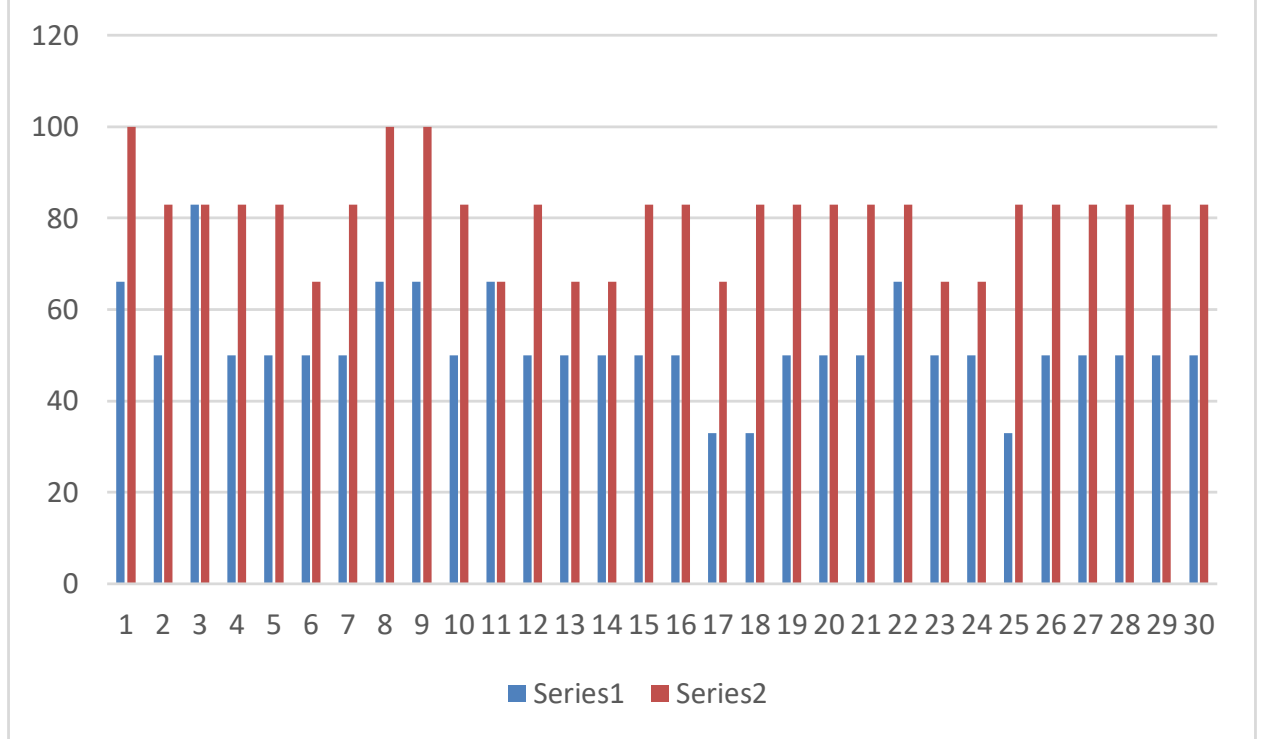

Sumber: Data diolah peneliti (2021)

\section{Grafik 1. Perbandingan Kemampuan Berpikir Kritis Peserta Didik Apabila Ditinjau Per Individu}


1770 Efektivitas Model Pembelajaran Blended Learning Untuk Meningkatkan Keterampilan Berpikir Kritis Peserta Didik Pada Pelajaran Ekonomi - Husaeri Ardika Dwi Putra, Dhiah Fitrayati

DOI: https://doi.org/10.31004/edukatif.v3i4.676

Adapun perolehan nilai dari pretest dan posttest setiap peserta didik bisa dilihat pada tabel 1. Sebelum mendapatkan perlakuan, nilai pretest terendah mencapai 33, sedangkan nilai pretest tertinggi mencapai 83. Namun setelah diberikan perlakuan, nilai posttest terendah mencapai 66 dan nilai tertinggi mencapai 100 .

Distribusi sampel atau subjek tergolong normal atau tidak dianalisis dengan uji normalitas. Subjek dinyatakan tidak normal apabila nilai signifikansi atau nilai probabilitas dinyatakan $<0,05$ dan apabila $>0,05$ maka distribusi subjek penelitian normal. Pada uji normalitas tingkat signifikansi uji normalitas Kolmogorov Smirnov pada soal pre-test yaitu $0.000<0.05$ sehingga distribusi subjek penelitian adalah tidak normal. Sedangkan tingkat signifikansi uji normalitas Kolmogorov Smirnov pada soal post-test yaitu $0.000<0.05$ sehingga distribusi subjek penelitian adalah tidak normal.

Selanjutnya uji wilcoxon digunakan untuk menghitung peningkatan keterampilan berpikir kritis. Uji wilcoxon diterapkan karena data terdistribusi tidak normal. Uji wilcoxon menggunakan nilai pre-test dan posttest dari subjek untuk dianalisis dampak dari pembelajaran model pembelajaran blended learning. Ho diterima apabila tingkat Asymp.Sig (2-tailed) $<0.05$ dan apabila tingkat Asymp.Sig (2-tailed) > 0.05 Ho ditolak.

Tabel 2

Hasil Uji Wilcoxon

\begin{tabular}{llrrr}
\hline & $\mathrm{N}$ & Mean Rank & Sum of Ranks \\
\hline Post Test - Pre Test & Negative Ranks & $0^{\mathrm{a}}$ & .00 & .00 \\
\cline { 2 - 5 } & Positive Ranks & $28^{\mathrm{b}}$ & 14.50 & 406.00 \\
\cline { 2 - 5 } & Ties & $2^{\mathrm{c}}$ & & \\
\cline { 2 - 5 } & Total & 30 & & \\
\hline
\end{tabular}

Sumber: Data diolah peneliti (2021)

Dari tabel diatas diketahui:

1. Negative Ranks atau selisih (negatif) antara hasil Pre Test dan Post Test yaitu 0 yang menunjukkan nilai pretest ke posttest tidak menurun.

2. Positif Ranks atau selisih (positif) antara hasil Pre Test dan Post Test. Disini terdapat 28 data positif (N) yang artinya ke 28 peserta didik mengalami peningkatan hasil dari nilai Pre Test ke nilai Post Test. Mean Rank atau rata-rata peningkatan tersebut adalah sebesar 14.50, sedangkan jumlah rangking positif atau Sum of Ranks adalah sebesar 406.00.

3. Ties adalah kesamaan nilai Pre Test dan Post Test, disini nilai Ties adalah 2, sehingga dapat dikatakan bahwa ada nilai yang sama antara Pre Test dan Post Test.

Bisa disimpulkan model pembelajaran blended learning yang diterapkan mampu meningkatkan keterampilan berpikir kritis peserta didik.

Proses pembelajaran dilaksanakan setiap hari jumat untuk menyesuaikan dengan jadwal pelajaran ekonomi kelas XI IPS 2 dan malam sebelum proses pembelajaran dilaksanakan sebagai penerapan asinkronus mandiri. Penelitian pertama dilaksanakan pada tanggal 26 Februari 2021 pada saat malam hari dengan mengirimkan soal pre-test dan materi pembelajaran yang akan dibahas keesokan harinya. Proses pembelajaran dilanjutkan keesokan harinya dengan menerapkan seluruh langkah-langkah pembelajaran blended learning. Penelitian kedua dilaksanakan pada tanggal 5 Maret 2021 dengan mengirimkan materi dan studi kasus yang akan dibahas keesokan harinya. Pembelajaran kemudian dilanjutkan pada keesokan harinya. Penelitian ketiga dilaksanakan pada tanggal 12 Maret 2021 dengan mengirimkan materi dan studi kasus yang akan dibahas keesokan harinya. Pembelajaran kemudian dilanjutkan pada keesokan harinya pada tanggal 13 Maret 2021 dikarenakan ini pertemuan terakhir maka soal post-test dibagikan kepada peserta didik untuk dikerjakan.

Pembelajaran yang dilaksanakan menggunakan model blended learning tiga ruang yaitu sinkronus virtual, asinkron mandiri, dan asinkron kolaboratif. Pada pembelajaran asinkronus mandiri guru 
1771 Efektivitas Model Pembelajaran Blended Learning Untuk Meningkatkan Keterampilan Berpikir Kritis Peserta Didik Pada Pelajaran Ekonomi - Husaeri Ardika Dwi Putra, Dhiah Fitrayati

DOI: https://doi.org/10.31004/edukatif.v3i4.676

menginformasikan tentang proses pembelajaran yang akan dilaksanakan keesokan harinya agar peserta didik lebih siap untuk memulai pembelajaran. Selanjutnya guru memberikan materi untuk dipelajari peserta didik terlebih dahulu agar pada saat pembelajaran tatap muka secara virtual peserta didik sudah memiliki sedikit pemahaman tentang materi yang akan dibahas dan dapat aktif pada proses pembelajaran. Guru menginstruksikan kepada peserta didik untuk membentuk kelompok dengan tujuan mendiskusikan studi kasus yang telah diunggah guru pada whatsapp grup, hal ini melatih kemampuan berdiskusi peserta didik. Jadi, pada pembelajaran asinkronus mandiri ini merupakan tahap persiapan untuk mendorong keaktifan peserta didik dan siap untuk melaksanakan pembelajaran pada keesokan harinya.

Pada pembelajaran sinkronus virtual dilaksanakan menggunakan aplikasi video conference yaitu google meet. Proses pembelajaran dilaksanakan pada pukul 08.30 dengan estimasi keterlambatan 15 menit dan selesai pada pukul 10.00. Pada pembelajaran sinkronus terdapat pendahuluan, kegiatan inti, dan penutup.

Tahap pendahuluan dibuka dengan guru menginstruksikan untuk berdoa dan dilanjutkan memeriksa kehadiran. Guru kemudian memberikan motivasi peserta didik untuk tetap semangat dan tetap mematuhi protokol kesehatan yang telah disampaikan pemerintah agar dapat terhindar dari segala virus. Pada tahap ini guru menunjukkan tujuan pembelajaran dan mereview mengenai materi pembelajaran yang dilaksanakan pada pertemuan sebelumnya.

Pada tahap kegiatan inti terdapat dua fase yaitu akusisi informasi, dan mensintesiskan pengetahuan. Menurut Leicester dan Taylor (dalam Supriatna et al., 2020) bahwa pada fase akuisisi informasi sebelum guru menjelaskan materi pada pertemuan hari itu, guru terlebih dahulu mengajukan pertanyaan tentang materi yang telah dipelajari pada pembelajaran asinkronus mandiri untuk melatih aspek memberikan penjelasan sederhana. Pada fase ini guru menginstruksikan untuk menjelaskan apa yang telah dipahami terkait studi kasus yang telah diunggah guru, hal ini juga melatih kemampuan peserta didik pada aspek membuat penjelasan lebih lanjut. Selanjutnya pada fase mensintesiskan pengetahuan guru menyamakan pemahaman tentang konsep materi dan menyimpulkan materi yang dipelajari secara bersama.

Tahap penutup guru bertanya apakah ada yang ditanyakan mengenai materi yang dipelajari dan memberikan informasi mengenai studi kasus yang harus dikumpulkan peserta didik pada tahap pembelajaran asinkronus mandiri. Setelah semua pembelajaran telah dilaksanakan dan peserta didik tidak mengajukan pertanyaan maka pembelajaran akan ditutup dengan do'a.

Pada pembelajaran asinkronus mandiri setelah pembelajaran sinkronus dilaksanakan. Peserta didik berdiskusi secara virtual untuk menganalisis studi kasus. Hal ini dapat melatih kemampuan berpikir kritis pada aspek membuat penjelasan lebih lanjut. Pada tahapan ini guru sebagai fasilitator apabila ada yang ditanyakan mengenai kejelasan tugas. Pembelajaran berakhir disaat peserta didik telah mengunggah jawaban studi kasus pada whatsapp grup.

Berdasarkan hasil analisis uji Wilcaxon, diperoleh nilai Asymp.Sig. (2-tailed) bernilai 0,000. Karena nilai 0,000 lebih kecil dari < 0,05, maka dapat disimpulkan bahwa Hipotesis diterima. Artinya terdapat perbedaan antara hasil Pre Test dan Post Test, sehingga kesimpulannya ada pengaruh penggunaan metode pembelajaran blended learning mampu meningkatkan keterampilan berpikir kritis siswa.

Dalam implementasi proses pembelajaran dengan blended learning perlu rancangan yang matang untuk menciptakan proses pembelajaran yang bermakna dan keterampilan pada peserta didik (Zurita et al., 2015). Menurut Ananda dkk (dalam Ramadani et al., 2019) faktor tersebut mencakup sumber daya manusia, lingkungan belajar serta sarana dan prasarana. Sumber daya manusia disini mencakup pengajar sebagai tenaga ahli untuk menuntun dan membimbing peserta didik untuk dapat menjalankan proses pembelajaran secara efektif karena peserta didik secara langsung terlibat dalam proses pembelajaran sehingga mereka dituntut untuk dapat belajar mandiri dengan bimbingan pengajar secara daring. Lingkungan belajar merupakan faktor penunjang proses pembelajaran dengan model blended learning, dengan lingkungan belajar yang nyaman membuat peserta didik dapat menerima materi pembelajaran dengan maksimal dan dapat menuangkan 
1772 Efektivitas Model Pembelajaran Blended Learning Untuk Meningkatkan Keterampilan Berpikir Kritis Peserta Didik Pada Pelajaran Ekonomi - Husaeri Ardika Dwi Putra, Dhiah Fitrayati

DOI: https://doi.org/10.31004/edukatif.v3i4.676

kreatifitasnya. Sarana dan prasarana dalam model pembelajaran blended learning ini mencakup smartphone/laptop/computer dan jaringan internet untuk memudahkan dalam melakukan proses pembelajaran jarak jauh (Ramadani et al., 2019).

Pada perbandingan kemampuan berpikir kritis per individu. Berdasarkan hasil pretest dan posttest menunjukkan bahwa peserta didik mengalami peningkatan yang cukup baik. Dimana hasil pada pre test yang semula mendapat nilai rendah, setelah diberikan tindakan berupa model pembelajaran blended learning. Hasil pada post test mendapat nilai yang cukup tinggi dibandingkan nilai pada pre test. Pada saat uji deskriptif kemampuan berpikir kritis peserta didik memiliki hasil dan rata-rata lebih besar pada pengerjaan post test dibandingkan dengan pengerjaan pre test.

Dengan demikian penelitian untuk mengukur tingkat efektivitas model pembelajaran blended learning sebagai upaya peningkatan keterampilan dalam berpikir kritis dinyatakan efektif. Sejalan dengan penelitian dari (Idris, 2018), model pembelajaran berbasis blended learning memperluas jangkauan pembelajaran. Sebab model pembelajaran berbasis blended learning ini peserta didik bisa dapat belajar dari sumber manapun. Dibuktikan dengan hasil perbandingan keterampilan dalam berpikir kritis dan uji deskriptif keterampilan dalam berpikir kritis, diperoleh nilai dari pre test dan post test memiliki ketidaksamaan berupa peningkatan dari nilai individu dan rata-rata. Penelitian yang dilakukan oleh (Utomo \& Wihartanti, 2019) membuktikan bahwa hasil dari penerapan blended learning mampu meningkatkan keterampilan berpikir kritis peserta didik. Selain itu, pada penelitian (Anggraeni et al., 2019) memperoleh hasil bahwa blended learning dapat meningkatkan keterampilan berpikir kritis peserta didik secara signifikan.

Keterbatasan jaringan yang menjadi kendala peneliti dalam melakukan penelitian, karena SMA yang dijadikan untuk penelitian berada di daerah pedesaan yang sangat minimal dengan adanya jaringan internet. Selain itu peserta didik juga banyak yang tidak bisa bergabung pada pembelajaran zoom meet dikarenakan sedang membantu orang tua bekerja di ladang.

Memberikan sumbangsih terhadap berkembangnya teknologi yaitu peserta didik dapat belajar di rumah, tetapi bisa bertatap muka dengan guru. Bisa menggunakan zoom meet untuk tatap muka ataupun menggunakan whatsapp grup untuk sekedar materi.

\section{KESIMPULAN}

Sesuai dengan paparan hasil diatas, dapat disimpulkan model pembelajaran yang digunakan yaitu blended learning mampu meningkatkan keterampilan dalam befikir kritis. Dibuktikan dengan hasil perbandingan kemampuan berpikir kritis dan uji deskriptif keterampilan berpikir kritis pada perolehan nilai dari pre test dan post test memiliki ketidaksamaan berupa peningkatan dari nilai individu dan rata-rata.

\section{DAFTAR PUSTAKA}

Anggraeni, A., Supriana, E., \& Hidayat, A. (2019). Pengaruh Blended Learning terhadap Kemampuan Berpikir Kritis Siswa SMA pada Materi Suhu dan Kalor. Jurnal Pendidikan, 4(6), 758-763.

Cahyadi, F. D., Suciati, \& Probosari, R. M. (2012). Penerapan Blended Learning Dalam Pembelajaran Biologi Untuk Meningkatkan Kemampuan Berpikir Kritis Siswa Kelas Xi Ipa 4 Putra SMA RSBI Pondok Pesantren Modern Islam Assalaam Sukoharjo Tahun Pelajar 2011/2012. Pendidikan Biologi, 4(1), 1522. https://jurnal.uns.ac.id/bio/article/view/5532

Cronje, J. C. (2020). Towards a new definition of blended learning. Electronic Journal of E-Learning, 18(2), 114-135. https://doi.org/10.34190/EJEL.20.18.2.001

Educational, R. E.-, \& 1985, U. (2016). A Logical Basis for Measuring Critical Thinking Skills. A Logical Basis for Measuring Critical Thinking Skills, 11(1), 217-232.

https://pdfs.semanticscholar.org/80a7/c7d4a98987590751df4b1bd9adf747fd7aaa.pdf

Fariska, R., \& Erman. (2017). Blended Learning Untuk Meningkatkan Level Kemampuan Berpikir Kritis. 
1773 Efektivitas Model Pembelajaran Blended Learning Untuk Meningkatkan Keterampilan Berpikir Kritis Peserta Didik Pada Pelajaran Ekonomi - Husaeri Ardika Dwi Putra, Dhiah Fitrayati DOI: https://doi.org/10.31004/edukatif.v3i4.676

Pensa: Jurnal Pendidikan Sains, 5(02), 60-66.

Fisher, A. (2009). Berpikir Kritis: Sebuah Pengantar = Critical Thinking: An Introduction, penerjemah Benyamin Hadinata. http://lib.ui.ac.id/detail.jsp?id=20401661

Handarini, O. I., \& Wulandari, S. S. (2020). Daring to draw causal claims from non-randomized studies of primary care interventions. Pembelajaran Daring Sebagai Upaya Study From Home (SFH) Selama Pandemi Covid 19, 8(5), 639-643. https://doi.org/10.1093/fampra/cmy005

Hastjarjo, T. D. (2019). Rancangan Eksperimen-Kuasi. Buletin Psikologi, 27(2), 187. https://doi.org/10.22146/buletinpsikologi.38619

Hidayah, A. A. F., Al Adawiyah, R., \& Mahanani, P. A. R. (2020). Efektivitas Pembelajaran Daring di Masa Pandemi Covid 19. JURNAL SOSIAL :Jurnal Penelitian Ilmu-Ilmu Sosial, 21(September), 53-56. http://sosial.unmermadiun.ac.id/index.php/sosial/article/view/61

Idris, H. (2018). Pembelajaran Model Blended Learning. Jurnal Ilmiah Iqra', 5(1), 61-73. https://doi.org/10.30984/jii.v5i1.562

Indrawan, B., \& Kaniawati Dewi, R. (2020). Pengaruh Net Interest Margin (NIM) Terhadap Return on Asset (ROA) Pada PT Bank Pembangunan Daerah Jawa Barat Dan Banten Tbk Periode 2013-2017. Jurnal EBis (Ekonomi-Bisnis), 4(1), 78-87. https://doi.org/10.37339/e-bis.v4i1.239

Lestari, D., Mulyani, E. ., \& Susanti, R. (2016). Pengembangan Perangkat Blended Learning Sistem Saraf Manusia Untuk Meningkatkan Keterampilan Berpikir Kritis. Journal of Innovative Science Education, 5(1), 83-93. http://journal.unnes.ac.id/sju/index.php/jise

López-Pérez, M. V., Pérez-López, M. C., \& Rodríguez-Ariza, L. (2011). Blended learning in higher education: Students' perceptions and their relation to outcomes. Computers and Education, 56(3), 818 826. https://doi.org/10.1016/j.compedu.2010.10.023

Ningsih, W. S. A., Suana, W., \& Maharta, N. (2018). Pengaruh Penerapan Blended Learning Berbasis. Jurnal Tarbawi : Jurnal Ilmu Pendidikan, 3(02), 85-93.

http://jurnalkonstan.ac.id/index.php/jurnal\%0APENGARUH

Prastowo, A., Mujadi, M., Purnaida, P., \& Santosa, B. R. (2019). Pembelajaran Keterampilan Berpikir Kritis: Studi Kasus Di Mim Ngipik Dan Mim Dondong Kulonprogo. Edukasia : Jurnal Penelitian Pendidikan Islam, 13(2), 305-328. https://doi.org/10.21043/edukasia.v13i2.3525

Rachmantika, A. R., \& Wardono. (2019). Peran kemampuan berpikir kritis siswa pada pembelajaran matematika dengan pemecahan masalah. Prosiding Seminar Nasional Matematika, 2, 439-443.

Ramadani, A. D., Sulthoni, \& Wedi, A. (2019). Faktor-Faktor Yang Berpengaruh Terhadap Implementasi Blended Learning Di Jurusan Teknologi Pendidikan Universitas Negeri Malang. Jurnal Kajian Teknologi Pendidikan, 2(1), 62-67. http://journal2.um.ac.id/index.php/jktp/article/download/7678/3910

Ratu, D., Uswatun, A., \& Pramudibyanto, H. (2020). Pendidikan Dalam Masa Pandemi Covid-19. Jurnal Sinestesia, 10(1), 41-48. https://sinestesia.pustaka.my.id/journal/article/view/44

Safriandi, Syahriandi, Radhiah, \& Trisfayani. (2021). Keefektifan Perkuliahan Daring Pada Masa Covid-19 Di Prodi Pendidikan Bahasa Indonesia Universitas Malikussaleh. 8848(1), 187-196.

Sari, D. P., \& Dewi, R. M. (2017). Pengaruh Keterampilan Berpikir Kritis Dan Berpikir Kreatif Terhadap Hasil Belajar Mata Pelajaran Ekonomi Kelas X Ips 1 Di Man Mojosari. Edisi Yudisium, 5(1), 1-8.

Satwika, Y. W., Laksmiwati, H., \& Khoirunnisa, R. N. (2018). Penerapan Model Problem Based Learning untuk Meningkatkan Kemampuan Berfikir Kritis Mahasiswa. Jurnal Pendidikan (Teori Dan Praktik), 3(1), 7. https://doi.org/10.26740/jp.v3n1.p7-12

Sharma, P. (2010). Blended learning. ELT Journal, 64(4), 456-458. https://doi.org/10.1093/elt/ccq043

Sukirwan. (2020). PEMBELAJARAN DARI RUMAH: DARI KLASIKAL KE DIGITAL. Journal of Chemical Information and Modeling, 21(1), 1-9. 
1774 Efektivitas Model Pembelajaran Blended Learning Untuk Meningkatkan Keterampilan Berpikir Kritis Peserta Didik Pada Pelajaran Ekonomi - Husaeri Ardika Dwi Putra, Dhiah Fitrayati

DOI: https://doi.org/10.31004/edukatif.v3i4.676

https://doi.org/10.1016/j.tmaid.2020.101607\%0Ahttps://doi.org/10.1016/j.ijsu.2020.02.034\%0Ahttps://o nlinelibrary.wiley.com/doi/abs/10.1111/cjag.12228\%0Ahttps://doi.org/10.1016/j.ssci.2020.104773\%0A https://doi.org/10.1016/j.jinf.2020.04.011\%0Ahttps://doi.o

Supriatna, I., Agusdianita, N., Yuliantini, N., Herman, H., \& Resnani, R. (2020). Reading Comprehension through the FIVES Model and Guided Reading Model to Improve Critical Thinking Ability in the Industrial Revolution Era 4.0. Mimbar Sekolah Dasar, 7(1), 133-152. https://doi.org/10.17509/mimbarsd.v7i1.22500

Susandi, A. (2017). The Influence Model Blanded Learning of Social Sciences Subjects Respecting Indonesian Ethnic and Cultural Diversity To Increasing Activity And Learning Outcomes of Grade V Students in Elementary School 1 Purwoharjo Banyuwangi Distric Year 2015/2016. Pancaran Pendidikan, 6(3). https://doi.org/10.25037/pancaran.v6i3.44

Utomo, S. W., \& Wihartanti, L. V. (2019). Penerapan Strategi Blended Learning Untuk Meningkatkan Kemampuan Berpikir Kritis Mahasiswa Pada Era Revolusi Industri 4.0. Kwangsan: Jurnal Teknologi Pendidikan, 7(1), 30-44. https://doi.org/10.31800/jtp.kw.v7n1.p30--44

Wardani, D. N., Toenlioe, A. J. E., \& Wedi, A. (2018). Daya Tarik Pembelajaran Di Era 21 Dengan Blended Learning. Jurnal Kajian Teknologi Pendidikan (JKTP), 1(1), 13-18.

Yoga Purandina, I. P., \& Astra Winaya, I. M. (2020). Pendidikan Karakter di Lingkungan Keluarga Selama Pembelajaran Jarak Jauh pada Masa Pandemi COVID-19. Cetta: Jurnal Ilmu Pendidikan, 3(2), 270 290. https://doi.org/10.37329/cetta.v3i2.454

Yu, Z. (2015). Blended learning over two decades. In Professional Development and Workplace Learning: Concepts, Methodologies, Tools, and Applications (pp. 1248-1267). IGI Global. https://doi.org/10.4018/978-1-4666-8632-8.ch068

Yulfianti, S. Y., \& Dewi, R. M. (2021). Jurnal Kependidikan : Efek Learning Management System Berbasis Google Classroom dan Minat Belajar Terhadap Hasil Belajar Ekonomi Siswa Septenti Yuti Yulfianti *, Retno Mustika Dewi Fakultas Ekonomi dan Bisnis, Universitas Negeri Surabaya * Corresponding. 7(2), 491-502.

Zurita, G., Hasbun, B., Baloian, N., \& Jerez, O. (2015). A blended learning environment for enhancing meaningful learning using $21 \mathrm{st}$ century skills. Lecture Notes in Educational Technology, 9783662441879, 1-8. https://doi.org/10.1007/978-3-662-44188-6_1 